\title{
PENGARUH SENAM PRENATAL YOGA TERHADAP KESIAPAN IBU PRIMIGRAVIDA DALAM MENGHADAPI PERSALINAN DI BPM KOTA BENGKULU
}

\author{
Yuniarti, Eliana \\ Politeknik Kesehatan Kementerian Kesehatan Bengkulu, Jurusan Kebidanan \\ yuniartoyouni@yahoo.com
}

\begin{abstract}
For a primigravida first face pregnancy, when the face of the delivery process tends to unpreparedness this is because labor is something new was going to happen. Practicing yoga exercises during this period is one of self-help solutions which support the process of pregnancy, birth, both physically and psychologically The purpose of this study is expected to influence prenatal yoga exercises on the readiness of labor in primigravida face BPM in Bengkulu City in 2015. This research uses quasiexperimental methods, the sampling technique with purposive sample totaling totaling 30 samples comprising 15 people carry out prenatal yoga exercises (cases) 15 people given pregnancy exercise (control). Data collection techniques directly to the two groups of pregnant women primigravidae Trimester III before the intervention were given a questionnaire to see the birth preparedness, further intervention group prenatal yoga exercises 2 times a week for 1 month, analysis of the data used test sample t test. Univariate results obtained an average yield of readiness before the intervention prenatal yoga exercises in the face of normal delivery was 19,67 after intervention decreased to 10,80 , bivariate analysis obtained $p$ value: $0,005<\alpha 0,05$, which means there is the influence of prenatal yoga exercise on preparedness primigravida in the face of labor in BPM in the city of Bengkulu 2015. For health workers, especially midwives do prenatal yoga training exercise in pregnant women and can be taught to pregnant women for prenatal yoga exercises melakukakan useful for Preparing mother both physically and psychologically in the face of labor
\end{abstract}

Keywords: Prenatal yoga Gymnastics, Readiness

\begin{abstract}
Abstrak: Primigravida yang pertama kali menghadapi kehamilan, ketika wajah persalinan cenderung tidak siap karena persalinan adalah sesuatu yang baru yang akan terjadi. Berlatih yoga selama periode ini adalah salah satu solusi mandiri yang mendukung proses kehamilan, kelahiran, baik secara fisik maupun psikologis. Tujuan dari penelitian ini dapat mempengaruhi praktik yoga prenatal pada kesiapan tenaga kerja di primigravida yang menghadapi BPM di Kota Bengkulu. pada tahun 2015. Penelitian ini menggunakan metode kuasi-eksperimental, teknik pengambilan sampel dengan sampel purposif sebanyak 30 sampel yang terdiri dari 15 orang melakukan latihan yoga prenatal (kasus) 15 orang diberi pelatihan kehamilan (kontrol). Teknik pengumpulan data langsung ke dua kelompok wanita hamil primigravidae Trimester III sebelum intervensi diberikan kuesioner untuk melihat kesiapan persalinan, kelompok intervensi latihan yoga prenatal lanjut 2 kali seminggu selama 1 bulan, analisis data menggunakan uji t sampel. Hasil univariat diperoleh kesiapan rata-rata sebelum intervensi latihan yoga prenatal dalam menghadapi persalinan normal adalah 19,67
\end{abstract}


setelah intervensi menurun menjadi 10,80, analisis bivariat memperoleh nilai p: 0,005 $<\alpha 0,05$, yang berarti ada efek latihan prenatal yoga tentang kesiapan primigravida dalam menghadapi persalinan di BPM di kota Bengkulu 2015, petugas kesehatan, terutama bidan yang melakukan latihan yoga prenatal untuk wanita hamil dan dapat diajarkan kepada wanita hamil untuk melakukan latihan yoga prenatal yang berguna untuk mempersiapkan ibu baik secara fisik maupun psikologis dalam menghadapi persalinan.

Kata Kunci: Latihan yoga prenatal, Kesiapan

Berdasarkan Target MDGs pada tahun 2015 angka kematian ibu maksimal 102 per 100 ribu kelahiran dan angka kematian bayi 32 per 100 ribu kelahiran, di Indonesia angka kematian Ibu dan Bayi masih tinggi, berdasarkan hasil Survei Demografi dan Kesehatan Indonesia (SDKI) tahun 2012 didapatkan angka kematian ibu mencapai 359 per 100 ribu kelahiran hidup (Kementrian Kesehatan RI, 2013).

Kematian bayi baru lahir di Indonesia terutama disebabkan oleh prematuritas (32\%), asfiksia (30\%), infeksi $(33,6 \%)$, tetanus $(31,4 \%)$. (Kemenkes RI 2008).Persalinan lama merupakan salah satu penyebab tingginya AKI di Indonesia. Beberapa faktor yang berkontribusi terjadinya persalinan lama antara lainpower atau kekuatan ibu saat melahirkan tidak efektif, bayi yang terlalu besar, ketidaksesuaian ukuran panggul dengan kepala bayi dan psikologis (kecemasan) ibu yang tidak siap menghadapi persalinan. Sebagian besar kaum wanita menganggap bahwa kehamilan dan persalinan adalah peristiwa kodrat yang harus dilalui, tetapi sebagian wanita menganggap sebagai peristiwa khusus yang sangat menentukan kehidupan selanjutnya, kehamilan dan persalinan pada seorang wanita merupakan suatu siklus yang normal dan alamiah, akan tetapi siklus itu tetap mejadi resiko dan beban tersendiri bagi seorang wanita (Rochjati, 2003). Bagi seorang ibu primigravida yang pertama kali menghadapi kehamilan, ketika menghadapi proses persalinan cenderung mengalami kecemasan, hal ini dikarenakan proses persalinan adalah sesuatu hal baru yang akan dialaminya, kecemasan merupakan perasaan tidak nyaman yang biasanya berupa perasaan gelisah, takut atau khawatir yang merupakan manifestasi dari faktor psikologis dan fisiologis (Bobak, Lowdernik \& Jensen, 2005).

Salah satu hormon yang meningkat selama kehamilan adalah hormon adrenalin. Hormon adrenalin dapat menimbulkan disregulasi biokimia tubuh sehingga muncul ketegangan fisik pada ibu hamil seperti mudah marah, gelisah, tidak mampu memusatkan pikiran, raguragu bahkan mungkin ingin lari dari 
kenyataan hidup (Dariyo, 1997 dalam Wulandari, 2006). Menurut Pieter dan Lubis (2010) ibu hamil akan mengalami bentuk-bentuk perubahan psikis yaitu perubahan emosional, cenderung malas, sensitif, gampang cemburu, minta perhatian lebih, perasaan tidak nyaman, depresi, stress, dan mengalami kecemasan.

Pada umumnya wanita yang sedang hamil takut menghadapi proses persalinan Karena rasa sakit yang menimbulkan perasaan takut dan cemas. Hal ini dapat menimbulkan ketegannga jiwa dan fisik yang akan mengakibatkan kakunya oto-otot dan persendian yang tidak wajar. Stress atau kecemasan tersebut terkait dengan rasa sakit dan keluhan somatik lain yang sering terjadi, menurut hasil penelitian sekitar $70 \%$ dari ibu hamil mengalami sakit pinggang (low back pain) yang mungkin dimulai sejak awal trimester, puncaknya terjadi pada trimester III (Amy. 2009)

Gangguan psikologis pada ibu hamil dapat memperburuk perkembangan janin, pada ibu hamil yang mengalami stress yang berkepanjangan dapat menimbulkan hambatan perkembangan pada janin termasuk gangguan emosi setelah kelahiran, salah satu intervensi yang dilakukan adalah latihan fisik, alternative terapi pemijatan dan terpi energy seperti massage, acupressure, tharapetik touch dan healing touch dan mindbody, healing seperti imagery, meditasi/yoga, berdoa, refleksi dan biofeedback, berdasarkan hasil penelitian Woorely et All (2011) yoga dapat mengurangi tingkat kecemasan $14 \%$ hormone stress serta penelitian Beddoe (2009) yoga dapat mengarangi kecemasan pada ibu hamil.

Berlatih senam hamil pada masa ini merupakan salah satu solusi self help yang menunjang proses kehamilan, kelahiran dan bahkan pengasuhan anak yang dapat dilakukan dalam kelas antenatal, yang merupakan sarana untuk belajar kelompok tentang kesehatan ibu hamil. Senam hamil salah satunya adalah yoga. Yoga adalah sejenis olah tubuh, pikiran dan mental yang sangat membantu ibu hamil melenturkan persendian dan menenangkan pikiran terutama dalam trimester III. Senam hamil yoga memilki lima cara yaitu latihan fisik yoga, pernafasan (pranayama), positions (mudra), meditasi dan deep relaksasi yang dapat digunakan untuk mendapatkan manfaat selama kehamilan yang dapat membantu kelancaran dalam kehamilan dan kelahiran anak secara alami dan dapat membantu danlam memastikan bayi sehat. (Indriati, 2009).Berdasarkan penelitian yang dilakukan oleh rusmita (2011) ada pengaruh senam yoga terhadap kesipan ibu menghadapi persalinan.

Hasil studi pendahuluan menunjukkan bahwa dari 10 ibu hamil primigravida terdapat 6 orang $(60 \%)$ menyatakan cemas dan belum siap dalam 
menghadapi proses persalinan karena belum adanya pengalaman,dan takut tidak dapat melahirkan dengan normal, seluruh ibu $(100 \%)$ belum pernah melaksanakan senam yoga.

\section{BAHAN DAN CARA KERJA}

Desain yang digunakan dalam penelitian ini adalah metode quasieksperimen dengan pre dan post test. Analisa data yang digunakan uji $t$-Test

Sampel terdiri 2 Kelompok yaitu kelompok yang di intervensi dengan senam prenatal yoga dan kelompok sebagai kontrol dengan senam hamil, masing-masing kelompok sebanyak 15 orang jadi jumlah sampel 30 orang. Teknik pengambilan sampel dengan purposive sample, dengan kriteria inklusi : primigravida hamil trimester III tidak mengkonsumsi anti depresi, perencanan persalinan normal, Kriteria ekslusi : kehamilan dengan komplikasi, letak janin abnormal dan tidak bersedia menjadi responden.

Teknik pengumpulan data secara langsung kepada dua kelompok ibu hamil primigravida Trimester III sebelum diintervensi diberi kuisioner untuk melihat kesiapan menghadapi persalinan, selanjutnya diintervensi satu kelompok senam prenatal yoga 2 kali seminggu selama 8 minggu, dan satu kelompok dengan senam hamil setelah di intervensi dilihat kesiapan menghadapi persalinan
HASIL

\section{Analisa Univariat}

Analisa ini dilakukan untuk memperoleh karakteristik responden, rata-rata tingkat kesiapan sebelum dan sesudah intervensi dengan menggunakan senam prenatal yoga dan senam hamil.Hasil distribusi tersebut dapat dilihat dari tabel dibawah ini :

\begin{tabular}{|c|c|c|c|c|c|}
\hline Tabel & $\begin{array}{c}1 \quad \text { I } \\
\text { pendidika } \\
\text { BPM Kot }\end{array}$ & $\begin{array}{l}\text { tribusi } \\
\text { dan peke } \\
\text { Bengkulu }\end{array}$ & $\begin{array}{l}\text { rekuens } \\
\text { aan Ibu } \\
\text { hun } 20\end{array}$ & $\begin{array}{r}\text { ka } \\
\text { rimi }\end{array}$ & $\begin{array}{l}\text { kteristik } \\
\text { avida di }\end{array}$ \\
\hline \multirow[b]{2}{*}{ No } & \multirow[b]{2}{*}{ Variabel } & \multicolumn{2}{|c|}{ Kasus } & \multicolumn{2}{|c|}{ Kontrol } \\
\hline & & Jumlah & $\begin{array}{c}\text { Perse } \\
\text { ntase } \\
(\%)\end{array}$ & $\begin{array}{l}\text { Jum } \\
\text { lah }\end{array}$ & $\begin{array}{c}\text { Perse } \\
\text { ntase } \\
(\%)\end{array}$ \\
\hline \multirow[t]{3}{*}{1} & Pendidika & & & & \\
\hline & $\mathrm{n}:$ & 3 & 20 & 2 & 13,3 \\
\hline & $\begin{array}{l}\text { Rendah } \\
\text { Tinggi }\end{array}$ & 12 & 80 & 13 & 86,7 \\
\hline \multirow[t]{4}{*}{2} & Pekerjaan & & & & \\
\hline & $:$ & 13 & 86,7 & 11 & 73,3 \\
\hline & Tidak & 2 & 13,3 & 4 & 26,7 \\
\hline & $\begin{array}{l}\text { Bekerja } \\
\text { Total }\end{array}$ & 30 & 100 & 30 & 100 \\
\hline
\end{tabular}

Berdasarkaan table 1 pada kelompok kasus hampir sebagian besar (80\%) ibu hamil berpendidikan tinggi sedangkan pada kelompok kontrol hampir sebagian besar $(86,7 \%)$ ibu hamil berpendidikan tinggi. Untuk pekerjaan pada kelompok kasus hampir seluruh ibu hamil $(86,7 \%)$ bekerja sedangkan pada kelompok kontrol hampir sebagian besar ibu hamil $(73,3 \%)$ bekerja.

Tabel 2 : Nilai Rata-rata Kesiapan Sebelum Intervensi dan Setelah Intervensi dengan Senam Hamil dan Senam Prenatal Yoga Ibu Primigravida Di BPM Kota Bengkulu Tahun 2015.

\begin{tabular}{ccccc}
\hline No & Variabel & Mean & Median & $\begin{array}{c}\text { Standar } \\
\text { Deviasi }\end{array}$ \\
\hline 1 & $\begin{array}{l}\text { Senam Hamil } \\
\text { (Kontrol) : } \\
\text { - Kesiapan }\end{array}$ & 11,47 & 11,00 & 4,642 \\
& $\begin{array}{l}\text { Ibu } \\
\text { Sebelum }\end{array}$ & 12,69 & 11,00 & 7,735 \\
& & & \\
\hline
\end{tabular}




\begin{tabular}{|c|c|c|c|c|}
\hline \multirow{3}{*}{2} & $\begin{array}{l}\text { Intervensi } \\
\text { - Kesiapan } \\
\text { Ibu Setelah } \\
\text { Intervensi }\end{array}$ & & & \\
\hline & $\begin{array}{l}\text { Senam Yoga } \\
\text { (Kasus) : } \\
\text { - Kesiapan }\end{array}$ & 19,67 & 18,00 & 9,678 \\
\hline & $\begin{array}{l}\text { Ibu } \\
\text { Sebelum } \\
\text { Intervensi } \\
\text { - Kesiapan } \\
\text { Ibu Setelah } \\
\text { Intervensi }\end{array}$ & 10,80 & 9,00 & 4,709 \\
\hline
\end{tabular}

Berdasarkaan table 2 diatas rata-rata tingkat kesiapan ibu sebelum intervensi dengan senam hamil nilai rata-rata 11,47 dan tingkat kesiapan setelah intervensi dengan senam hamil meningkat menjadi rata-rata 12,69 , sedangkan rata-rata tingkat kesiapan ibu sebelum intervensi dengan senam prenatal yoga nilai rata-rata 19,67 dan kesiapan setelah intervensi dengan senam prenatal yoga menurunt menjadi rata-rata 10,80

\section{Analisa Bivariat}

Analisa bivariat dilakukan untuk melihat perbedaan kecemasan sebelum intervensi dan setelah dilakukan intervensi di analisis dengan Independen sampel test wilcoxson dikarenakan data tidak berdistrubusi normal makadidapatkan hasil sebagai berikut :

Tabel 3 : Pengaruh Kesiapan Sebelum Intervensi Dan Setelah Intervensi dengan Senam Hamil Di BPM Kota Bengkulu Tahun 2015

\begin{tabular}{lcccc}
\multicolumn{1}{c}{ Variabel } & $\mathbf{n}$ & $\boldsymbol{p}$ & Mean & $\mathbf{Z}$ \\
\hline $\begin{array}{l}\text { Kesiapan sebelum } \\
\text { intervensi dan } \\
\text { setelah intervensi }\end{array}$ & 30 & $\begin{array}{c}0,31 \\
7\end{array}$ & 5,00 & -1.000 \\
\hline
\end{tabular}

Berdasarkan tabel 3 diketahui bahwa kesiapan setelah intervensi dengan senam prenatal hamil didapat nilai mean 5,00 dengan nilai $p=0,317>\alpha 0,05$. yang berarti tidak ada pengaruh kesiapan ibu primigravida dalammenghadapi persalinan setelah senam hamil di BPM Kota Bengkulu Tahun 2015.

Tabel 4 : Pengaruh Kesiapan Sebelum Intervensi Dan Setelah Intervensi dengan Senam Prenatal Yoga Di BPM Kota Bengkulu Tahun 2015

\begin{tabular}{|c|c|c|c|c|}
\hline Variabel & $\mathbf{N}$ & $p$ & Mean & $\mathbf{Z}$ \\
\hline $\begin{array}{l}\text { Kesiapan } \\
\text { sebelum } \\
\text { intervensi dan } \\
\text { setelah } \\
\text { intervensi } \\
\end{array}$ & 30 & 0,005 & 8,00 & -2.840 \\
\hline
\end{tabular}

Berdasarkan tabel 4 diketahui bahwa kesiapan setelah intervensi dengan senam hamil didapat nilai mean 8,00 dengan nilai $p=0,005<\alpha 0,05$ yang berarti ada pengaruh kesiapan ibu primigravida dalammenghadapi persalinan setelah senam prenatal yoga di BPM Kota Bengkulu Tahun 2015

Tabel 5 Perbedaan Senam hamil dengan Senam Prenatal Yoga Terhadap Kesiapan Ibu Primigravida Menghadapi Persalinan Di BPM Kota Bengkulu Tahun 2015

\begin{tabular}{llll}
\hline \multicolumn{1}{c}{ Variabel } & n & Mean & $\boldsymbol{P}$ \\
& & & \\
\hline Senam Hamil & 15 & 10,63 & 0,002 \\
Senam Prenatal & 15 & 20,37 & \\
Yoga & & & \\
\hline
\end{tabular}

Berdasarkan tabel 5 diketahui bahwa perbedaan senam hamil dengan senam 
prenatal yoga didapat dengan nilai $p=$ $0,005<\alpha 0,05$ yang berarti ada perbedaan senam hamil dengan senam prenatal yoga terhadap kesipan ibu hamil primigravida dalam menghadapi persalinan di BPM Kota Bengkulu Tahun 2015

\section{PEMBAHASAN}

Berdasarkan hasil penelitian data univariat didapat hasil sebelum dilakukan intervensi senam prenatal yoga didapat hasil rata-rata ibu dalam tidak siap dan setelah dilakukan intervensi dengan senam prenatal yoga rata-rata ibu siap mengahadapi persalinan, ini berarti ada perbedaan senam prenatal yoga terhadap kesiapan ibu primigravida dalam menghadapi persalinan. Ini dikarena dengan senam prenatal yoga dapat mengurangi tingkat kesiapan 14\% hormone stress serta penelitian Beddoe (2009) yoga dapat mengurangi kecemasan pada ibu hamil sehingga ibu lebih siap menghadapi persalinan. Gangguan psikologis pada ibu hamil dapat memperburuk perkembangan janin, pada ibu hamil yang mengalami stress yang berkepanjangan dapat menimbulkan hambatan perkembangan pada janin termasuk gangguan emosi setelah kelahiran, salah satu intervensi yang dilakukan adalah latihan fisik, alternative terapi pemijatan dan terpi energy seperti massage, acupressure, tharapetik touch dan healing touch dan mindbody, healing seperti imagery, meditasi/yoga, berdoa, refleksi dan biofeedback, berdasarkan hasil penelitian Woorely et All (2011).

Dari hasil bivariat didapat nilai $p$ :0,005 yang berarti ada pengaruh kesiapan ibu primigravida dalammenghadapi persalinan setelah senam prenatal yoga. Hasil penelitian ini sejalan dengan penelitianrusmita (2011) bahwa ada pengaruh senam yoga terhadap kesiapan ibu menghadapi persalinan. Senam prenatal yoga memiliki lima cara yaitu latihan fisik yoga, pernafasan (pranayama), positions (mudra), meditasi dan deep relaksasi yang dapat digunakan untuk mendapatkan manfaat selama kehamilan yang dapat membantu kelancaran dalam kehamilan dan kelahiran anak secara alami dan dapat membantu dalam memastikan bayi sehat. (Indriati, 2009).

Hasil penelitian ini sesuai dengan teori yang menyatakan bahwa latihan senam yoga yang dilaksankan selama kehamilan secara teratur dan terprogram memberikan banyak manfaat baik bagi ibu maupun janin yakni dapat meningkatkan aliran darah, nutrisi janin secara adekuat serta berpengaruh pula pada organ reproduksi dan panggul (memperkuat otot perineum) untuk mempersipakan kehamilan secara alami, bila dicerna lebih lanjut senam yoga ibu hamil terkadung efek relaksasi yang dapat menstabilkan emosi ibu hamil sebab gerakan senam 
memfokuskan perhatian dan ritme napas, mengutamakan kenyamanan dan keamanan dalam berlatih (Krisnandi, 2010).

Berdasarkan hasil penelitian ini didapat bahwa ibu hamil yang melakukan senam prenatal yoga lebih siap fisik maupun psikologis dalam menghadapi persalinan dibandingkan dengan ibu yang tidak melakukan senam prenatal yoga, yakni senam hamil, hal ini sependapat dengan penelitian yang dilakukan Bedoe (2009) yang mengatakan bahwa senam prenatal yoga dapat meringankan edema dank ram yang sering terjadi pada ibu hamil trimester III dan menurut Nerendran (2005) dari Clinical Children Hospital Medikat Center di Ohio bahwa kehamilan yang berhubungan dengan tekanan darah tinggi lebih rendah kejadian pada kelompok yoga dbandingan dengan kelompok yang tidak yoga. Sependapat juga dengan penelitian Amy and Katryn (2008) pengaruh latihan yoga meningkatkan hasil kehamilan meliputi peningkatan aliran darah ke plasenta, penurunan hormon stress yang berasal dari ibu, termasuk kecemasan dan rasa sakit pada saat persalinan.

Hasil penelitian ini sesuia dengan teori Dariyo, dalam Wulandari, (2006) yaitu salah satu hormon yang meningkat selama kehamilan adalah hormon adrenalin, hormon adrenalin dapat menimbulkan disregulasi biokimia tubuh sehingga muncul ketegangan fisik pada ibu hamil seperti mudah marah, gelisah, tidak mampu memusatkan pikiran, raguragu bahkan mungkin ingin lari dari kenyataan hidup. Menurut Pieter dan Lubis (2010) ibu hamil akan mengalami bentukbentuk perubahan psikis yaitu perubahan emosional, cenderung malas, sensitif, gampang cemburu, minta perhatian lebih, perasaan tidak nyaman, depresi, stress, dan mengalami kecemasan sehingga tidak sipa menghadapi persalinan.

Berdasarkan hasil perbedaan senam prenatal yoga di dapat hasil nilai $p: 0,005$ yang berarti ada perbedaan kesiapan ibu primigravida dalammenghadapi persalinan dengan senam prenatal yoga dibandingkan dengan senam hamil biasa, ini dikarenakan senam prenatal yoga lebih efektik dibandingkan dengan senam hamil biasa, sesuai dengan teori Widdowson (2004) yang menyatakan bahwa senam prenatal yoga berbeda dengan senam hamil biasa, senam prenatal yoga diawali dengan pemberian penguatan atau dukungan sehingga ibu lebih termotivasi, dan gerakan yang diberikan dapat memperkuat otot panggul otot perineum yang dapat mempersipakan kehamilan secara alami.

Berdasarkan hasil penelitian ini didapat bahwa setelah melaksanakan senam prenatal yoga ibu hamil mengalami kesiapan menghadapi persalinan terbukti bahwa dari $20 \mathrm{ibu}$ hamil yang di intervensi dengan senam prenatal yoga 18 orang 
bersalin secara normal, dengan menerapkan teknik pernafasan yang dilaksanakan pada senam prenatal yoga pada saat menghadapi persalinan, hal ini sejalan dengan teori Widdowson (2004) bahwa teknik pernafasan dapat meredakan ketegangan baik ketegangan pada otot-otot tubuh maupun ketegangan yang muncul akibat menghadapi masa kehamilan, menguatkan rahim, meringankan beban pada perut, dan dapat membatu kelancaran proses persalinan.

Keterbatasan pada penelitian ini adalah senam prenatal yoga hanya dilaksankan pada trimester III, sedangkan secara teori sebaiknya dilaksankan mulai dari trimester I kehamilan, sehingga ibu lebih siap baik secara fisik, mental dan psikologis, maupun sosial, Pada penelitian ini juga variabel yang digunakan hanya kesiapan fisik dan psikis, tidak melihan sosial, diharapkan penelitian selanjutnya dapat menambahkan variable yang lebih banyak misalnya dukungan suami, dan kesiapan keuangan.

\section{DAFTAR RUJUKAN}

Amy E B and Kathryn A. Lee (2008) Mind-Body intervesion During Pregnancy JOGNN

Aprilia, Y. (2011). Siapa Bilang Melahirkan Itu Sakit. Yogyakarta: C.V Andi Offset

Arikunto, S. (2010). Prosedur Penelitian Edisi Revisi 2010. Jakarta: PT Rineka Cipta

Aprilia, Y. (2011). Mari Mempelajari Proses Persalinan. Diunduh pada tanggal 09 Oktober 2011 dari website : http://bidankita.com

Bobak, Lowdermilk, Jensen. (2005). Buku Ajar Keperawatan Maternitas. Jakarta: EGC

\section{KESIMPULAN}

Berdasarkan hasil dan pembahasan pengaruh senam yoga prenatal terhadap kesiapan ibu primigravida dalam menghadapi persalinan di BPM di Kota Bengkulu Tahun 2015 dapat disimpulkan sebagai berikut :Rata-rata kesiapan sebelum intervensi senam biasa 11,47, sedangkan senam prenatal yoga rata-rata kesiapan 19,67. Rata-rata kesiapan setelah intervensi senam biasa 12,69, sedangkan senam prenatal yoga rata-rata kesiapan 10,80. Ada pengaruh senam yoga prenatal terhadap kesiapan ibu primigravida dalam menghadapi persalinan.

Diharapkan bidan melakukan pelatihan senam prenatal yoga pada ibu hamil dan dapat mengajarkan pada ibu hamil untuk melakukakan senam prenatal yoga yang berguna untuk menyiapakan ibu baik fisik maupun psikologis dalam menghadapi persalinan.

Beddoe (2009), The Effects Of Mindfulness-Based Yoga During Pregnancy On Maternal Kelliat, A.B. (1999). Penatalaksanaan Stress. Jakarta: EGC

Psychological And Physical Distress, Jounal Article First Published Online: 12 may 2009 doi: 10.1111/j.1552-6909.2009.01023

Dahlan, M. S. (2011). Statistik untuk Kedokteran dan Kesehatan. Jakarta: Salemba Medika

Krisnadi (2010) Sipnosis Yoga Untuk Kehamilan Sehat Bahagia dan Penuh Makna, Jakarta 
Ilmiasih, R, \& Susanti, H. (2010). Pengaruh Tehnik Hypnobirthing Terhadap Tingkat Kecemasan Ibu Hamil Pada Masa Persiapan Menghadapi Persalinan. Malang: Universitas Muhamadiyah Malang. Diunduh pada tanggal 11 Februari 2012 dari website: http://research-report.umm.ac.id

Miami (2012), Tai Chi/Yoga Reduces Prenatal Depression, Anxiety And Sleep DisturbanceVolume 19, Issue 1, Pages 6-10

Musbikin, I. (2006). Persiapan Menghadapi Persalinan Dari Perencanaan Kehamilan Sampai Mendidik Anak. Yogyakarta: Mitra Pustaka

Narendran (2005), Efficacy Of Yoga On Pregnancy Outcome, Volume: 11 Issue 2: May 2, 2005the Journal Of Alternative And Complementary Medicine

Notoadtmojo (2008) Pendidikan Kesehantan, Sari Cipta, Jakarta
Perry et al, (2010) Maternal Child Nursing Care (4 thed) Elsevier Mosby

Prawiharjo (2002) Buku Acuan Nasional Pelayanan Maternal Dan Neonatal, Jakarta

Polit, DF \& Hungler DP (1995) Nursing Research Principles and Methods FifthEdition. Philadhelphia: J.B. Lippincot Company

Rochjati, P. (2003).Skrining Antenatal pada Ibu Hamil. Surabaya: Airlangga

Rusmita (2011), Pengaruh Senam yoga selama kelahiran terhadap kesiapan Fisik dan Psikologis dalam menghadapi persalinan pada Ibu Hamil trimester III di RSIA Limijati Bandung

Woolery (2004), A Yoga Intervention For Young Adults With Elevated Symptoms Of Depression, marlapr 2004, vol. 10, no. 2 Alternative Therapies

Widdoson (2004), Yoga untuk Masa Kehamilan, Esensi, Surabaya, Erlangga 